\title{
Synergistic immunomodulatory activity of probiotics Bifidobacterium animalis and Lactobacillus casei in Enteroaggregative Escherichia coli (EAEC)-infected Caco-2 cells
}

\author{
Andréa Fonseca FERREIRA, Ricardo Luís Lopes BRAGA, Maysa Ferreira ANDRADE, \\ Ana Claudia de Paula ROSA and Wânia Ferraz PEREIRA-MANFRO
}

Received: 3 February 2021 Accepted: 3 May 2021

\begin{abstract}
Background - Enteroaggregative Escherichia coli (EAEC) is an E. coli pathotype that presents aggregative adhesion patterns on in vitro cultivated cells, mainly related to persistent diarrhea cases in children. EAEC virulence factors are important for host colonization and pathogenicity. Intestinal epithelial cells (IECs) recognize pathogen-associated molecular patterns (PAMPs) and initiate an immune response. Several studies using in vivo and in vitro models emphasize the probiotic activity and immunomodulatory capacity of Lactobacillus and Bifidobacterium species. Objective - To evaluate the modulation of cytokine production by probiotics Bifidobacterium animalis and Lactobacillus casei in human intestinal Caco-2 cells exposed to different strains of EAEC. Methods - Caco-2 cells were incubated with EAEC strains in the presence or absence of probiotics. The production of cytokines IL-8, TNF- $\alpha$, IL-1 $\beta$ and IL-10 was evaluated in the supernatants by a sandwich enzyme-linked immunosorbent assay (ELISA). Results - Cytokine production did not change when uninfected and EAEC-infected Caco-2 cells were exposed to probiotics separately. All EAEC induced a significant increase in IL-8 production by Caco-2 cells, but the probiotics, even together, could not reduce its production. On the other hand, the synergic activity of probiotic strains significantly increased TNF- $\alpha$ production but decreased the basal production of IL-1B. Also, probiotics induced a significant increase in the production of the anti-inflammatory cytokine IL-10 during EAEC infection. Conclusion - Our results reinforce the synergistic immunomodulatory activity of probiotics during EAEC infection.
\end{abstract}

Keywords - Escherichia coli; probiotics; Bifidobacterium animalis; Lactobacillus casei; cytokines; epithelial cells; immunity.

\section{INTRODUCTION}

Intestinal infections caused by Escherichia coli are set due to infection by pathotypes of diarrheagenic E. coli (DEC) strains, which includes Enteroaggregative Escherichia coli (EAEC) ${ }^{(1)}$. This pathotype is recognized as the cause of persistent diarrhea in children, foodborne outbreaks, traveler's disease and intestinal infections of people infected with human immunodeficiency virus (HIV) $)^{(2,3)}$.

EAEC strains are characterized by manifesting aggregative adherence (AA) pattern ("stacked bricks") on HEp-2 cells and may present the aggregative adherence plasmid $(\mathrm{pAA})^{(1,4)}$. The pathogenesis of infection follows up three stages: (i) initial adherence to the mucosa and early colonization with biofilm formation; (ii) toxins secretion; and (iii) inflammatory response induction, cytokine secretion and mucosal damage ${ }^{(2)}$. Virulence genes, such as aggregative adherence fimbriae (AAF) located on pAA and cytotoxins are essential for EAEC colonization, which assure adherence and invasion, mediating inflammatory responses as well ${ }^{(5-7)}$. The inflam- matory response includes increased secretion of pro-inflammatory cytokines, leukocyte migration to the infected site and tissue damage, being close to diarrheal disease symptoms ${ }^{(8,9)}$. EAEC strains can promote IL-8, IL-1 $\beta$, IL- 6 , and TNF- $\alpha$ production by intestinal epithelial cells (IECs) as shown in studies using in vitro models and infected patients' analysis. However, the production of antiinflammatory cytokines such as IL-10 has not been detected ${ }^{(6,10,11)}$.

IECs play an essential role in the recognition of microorganisms in the intestinal lumen through pattern recognition receptors (PRRs) that recognize pathogen-associated molecular patterns (PAMPs), such as molecules expressed on the bacterial surface. Toll-like receptors (TLRs), which can be expressed on cell membranes, are important proteins included in the PRRs group. PAMPs are recognized by PRRs located on IECs membrane, resulting in intestinal cell activation. This process leads to different immune responses, managing colonization or infection progress ${ }^{(12,13)}$.

Probiotics are live non-pathogenic microorganisms found on different surfaces such as the urogenital and gastrointestinal mucosa that confer health benefits to the host as protection against

Declared conflict of interest of all authors: none

Disclosure of funding: this work was supported by Coordenação de Aperfeiçoamento de Pessoal de Nivel Superior-Brasil (CAPES) - Finance Code 001; Conselho Nacional de Desenvolvimento Científico e Tecnológico (CNPq), Fundação de Amparo à Pesquisa do Estado do Rio de Janeiro (FAPERJ) and Sub Reitoria de Pós Graduação e Pesquisa (SR-2/UERJ).

Universidade do Estado do Rio de Janeiro, Faculdade de Ciências Médicas, Departamento de Microbiologia, Imunologia e Parasitologia, Rio de Janeiro, RJ, Brasil.

Corresponding author: Wânia Ferraz Pereira Manfro. E-mail: waniafpm@gmail.com 
colonization by pathogens ${ }^{(14)}$. Probiotics are also found in fermented foods such as dairy products ${ }^{(15,16)}$. The group of lactic acid bacteria (LAB) includes Lactobacillus and Bifidobacterium genera and their species. These microorganisms are widely used in probiotic activity studies ${ }^{(17)}$.

Several studies report LAB probiotic activity against foodborne pathogens such as DEC, including their ability to reduce bacterial biofilm formation, reduce adherence, inhibit damage to in vitro cultured cells and prevent diarrhea on in vivo models. LAB also present antimicrobial properties and immunomodulatory capacity $^{(17,18)}$. This study investigated cytokines' production by Caco-2 cells exposed to different EAEC strains and their modulation by probiotics Bifidobacterium animalis and Lactobacillus casei.

\section{METHODS}

\section{Bacterial strains}

Four EAEC strains were included in this study. The prototype EAEC 042, EAEC I49 and EAEC H92/3 strains were previously isolated and characterized for putative virulence factors and adherence pattern $^{(11,19-21)}$. EAEC 1500 strain was isolated from faeces of hospitalized $\mathrm{HIV}^{+}$patients with persistent diarrhea in Rio de Janeiro. All EAEC strains were stored at $-80^{\circ} \mathrm{C}$ in Luria Broth (LB; Difco Laboratories) supplemented with 20\% glycerol (Merck).

Probiotic strains Bifidobacterium animalis DN 173010 (Activia - Danone ${ }^{\circledR}$ ) and Lactobacillus casei Shirota (Yakult ${ }^{\circledR}$ ), respectively identified as $B a$ and $L c$, were kindly provided by Paulo de Góes Microbiology Institute (Rio de Janeiro Federal University - UFRJ) or obtained from commercial products. Probiotic strains were stored at $-80^{\circ} \mathrm{C}$ in Man, Rogosa and Sharpe broth (MRS; Difco Laboratories) supplemented with $20 \%$ glycerol (Merck) and maintained on MRS agar (Difco Laboratories) at $4^{\circ} \mathrm{C}$.

\section{Cell culture and infection}

The human intestinal colon adenocarcinoma Caco-2 cell line (ATCC HTB37) was cultured in Dulbecco's Modified Eagle's Medium (DMEM) supplemented with $2 \%$ Fetal Bovine Serum (FBS) and antibiotics in 24-well plates for 14 days, when cell monolayers were polarized and differentiated. Infection with EAEC and probiotic strains was performed as previously described by Rosa et al. ${ }^{(22)}$ and Braga et al. ${ }^{(11)}$ with modifications.

Probiotic strains were cultured in $3 \mathrm{~mL}$ of MRS broth (Difco) and incubated for 48 hours at $37^{\circ} \mathrm{C}$ under anaerobic conditions. Bacterial EAEC strains were cultured in $3 \mathrm{~mL}$ of LB (Difco) and incubated for 18 hours at $37^{\circ} \mathrm{C}$. Aliquots of $100 \mu \mathrm{L}$ of EAEC and probiotics standardized suspensions (approximately $10^{7}$ CFU.mL $\mathrm{L}^{-1}$ ) were inoculated on the cell monolayers in triplicates. Caco-2 cells were exposed to EAEC strains, probiotics only, and $\mathrm{EAEC}+$ probiotics (each probiotic and both probiotics together). The plates were centrifuged at $2500 \mathrm{rpm}$ for five minutes at $15^{\circ} \mathrm{C}$ for synchronization and incubated for three hours. After incubation, the wells were washed and added DMEM medium supplemented with $2 \%$ of FBS, $1 \%$ D-mannose and $100 \mu \mathrm{g} / \mathrm{mL}$ amikacin (Teuto, Brazil). Plates were then cultured for additional 21 hours. Following a total of 24 hours of incubation, supernatants were collected, centrifuged, transferred to microtubes and stored at $-20^{\circ} \mathrm{C}$.

The production of cytokines IL-8, IL-1 $\beta$, TNF- $\alpha$ and IL-10 was measured in the supernatants by a sandwich enzyme-linked immunosorbent assay (ELISA), according to the manufacturer's instructions (R\&D Systems - Wiesbaden, Germany).

\section{Statistical analysis}

Cytokine concentrations were expressed as mean and standard error of mean (S.E.M) from three experiments performed independently. Statistical analyses were performed using Graph-Pad Prism version 7.0. Mann-Whitney test was performed to compare differences between different culture conditions and $P<0.05$ was considered statistically significant.

\section{RESULTS}

There was no significant change in the production of the cytokines IL-8, IL-1 $\beta$, IL-10 and TNF- $\alpha$ by Caco- 2 cells exposed to each probiotic alone or to EAEC in co-cultivation with probiotics $B a$ and $L c$ separately when compared to basal production by noninfected cells (data not shown).

IL- 8 production by Caco- 2 was significantly increased by EAEC strains $042(P=0.0004$, FIGURE 1.A), I49 ( $P=0.0008$, FIGURE 1.B), H92/3 $(P<0.0001$, FIGURE 1.C) and $1500(P=0.0004$, FIGURE 1.D) but not by the probiotics $B a+L c$ (FIGURE 1). The EAEC 042 strain (FIGURE 1.A) co-cultivated with probiotics also significantly increased IL-8 production when compared to non-infected cells $(P=0.0004)$ and cells exposed to both probiotics $(P=0.0496)$. Similar results were observed to EAEC I49 strain $(P=0.0008$ and $P=0.0319$, respectively, FIGURE $1 . B)$ and EAEC 1500 ( $P=0.0004$ and $P=0.039$, respectively, FIGURE $1 . D)$, but the amounts of IL- 8 induced by EAEC H92/3 in the presence of both probiotics were higher only when compared to basal production $(P=0.0003$, FIGURE 1.C). Interestingly, both probiotics, together with each EAEC strain, did not reduce the IL-8 production induced by the EAEC strains (FIGURE 1).

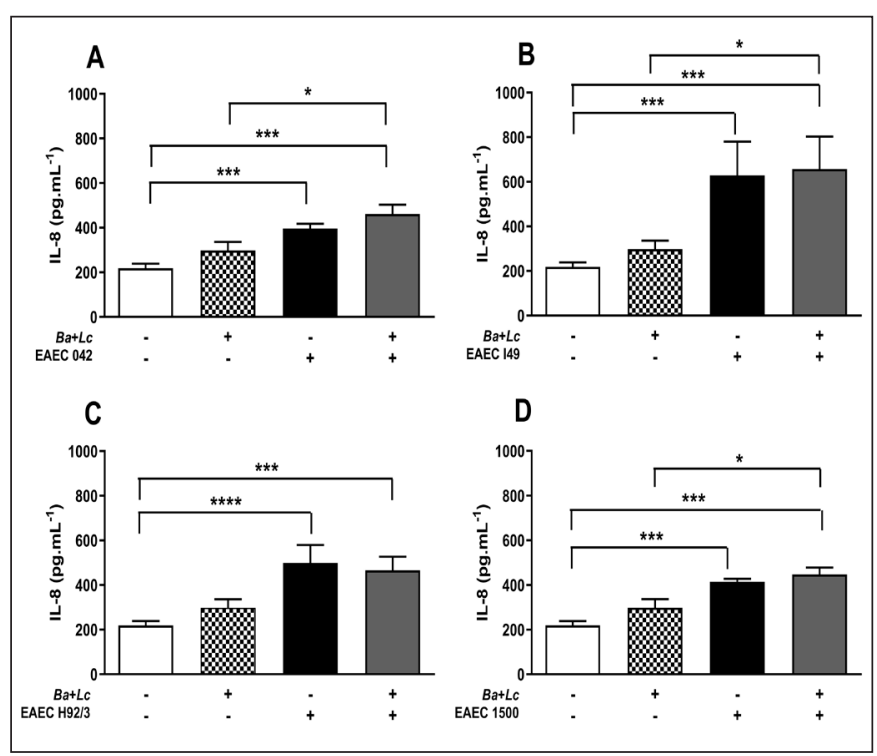

FIGURE 1. IL-8 production by uninfected Caco-2 cells (basal production), exposed to both probiotic strains $(B a+L c)$ and to EAEC $042(\mathrm{~A}), \mathrm{I} 49$ (B) $\mathrm{H} 92 / 3$ (C) and 1500 (D) strains in the absence and in the presence of both probiotics. Co-cultivation lasted for three hours and cells were cultured for additional 21 hours. Results are expressed as mean and S.E.M from three experiments performed independently. EAEC: Enteroaggregative Escherichia coli; Ba: Bifidobacterium animalis; Lc: Lactobacillus casei. Differences between culture conditions were calculated using Mann-Whitney test. $* P<0.05 ; * * * P<0.001 ; * * * * P<0.0001$ 
The infection of Caco-2 cells by EAEC strains used in this study did not induce IL-1 $\beta$ production (FIGURE 2 ). Importantly, Caco- 2 cells exposed only to $B a+L c$ probiotic strains reduced IL$1 \beta$ production significantly compared to basal levels $(P=0.0411$, FIGURE 2). Moreover, co-cultivation of the EAEC I49 (FIGURE 2.B) with both probiotics reduced significantly IL- $1 \beta$ production compared to cells infected only $(P=0.0095)$ and compared to basal production $(P=0.0216)$. Besides, probiotics, even in the presence of H92/3 (FIGURE 2.C) or 1500 strain (FIGURE 2.D), also reduced the production of IL-1 $\beta$ compared to basal levels $(P=0.0238$ and $P=0.0303$, respectively).

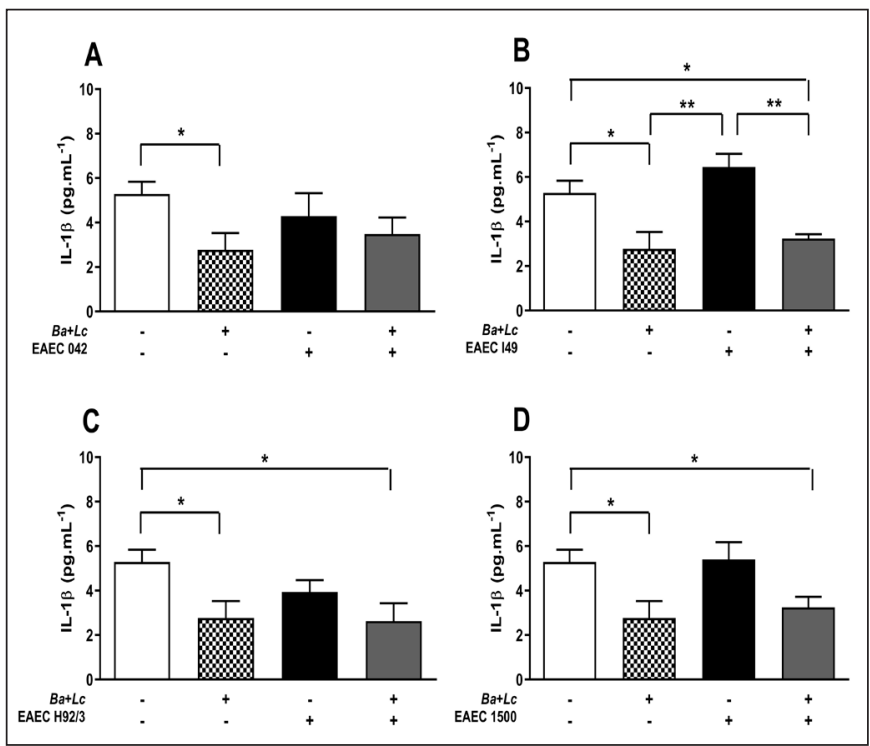

FIGURE 2 . IL-1 $\beta$ production by uninfected Caco- 2 cells (basal production), exposed to both probiotic strains $(B a+L c)$ and to EAEC 042 (A), I49 (B) H92/3 (C) and 1500 (D) strains in the absence and in the presence of both probiotics. Co-cultivation lasted for three hours and cells were cultured for additional 21 hours. Results are expressed as mean and S.E.M from three experiments performed independently. EAEC: Enteroaggregative Escherichia coli; Ba: Bifidobacterium animalis; Lc: Lactobacillus casei. Differences between culture conditions were calculated using Mann-Whitney test. $* P<0.05 ; * * P<0.01$.

As observed to IL-1 $\beta$, none of EAEC strains significantly modified TNF- $\alpha$ production (FIGURE 3 ). However, Caco-2 cells exposed to both probiotics showed higher levels of TNF- $\alpha$ production compared to basal ones $(P=0.026)$ and to EAEC strains $042(P=0.026$, FIGURE 3.A), H92/3 ( $P=0.0087$, FIGURE 3.C) and $1500(P=0.0087$, FIGURE 3.D). Furthermore, co-cultivation of EAEC strains 042 (FIGURE 3.A), I49 (FIGURE 3.B), H92/3 (FIGURE 3.C) and 1500 (FIGURE 3.D) with both probiotics induced significantly higher levels of TNF- $\alpha$ compared to the production by Caco- 2 cells alone $(P=0.0043, P=0.0022, P=0.0411$ and $P=0.011$, respectively) or to the EAEC infected ones $(P=0.0043$, $P=0.0022, P=0.0108$ and $P=0.0087$, respectively).

The production of anti-inflammatory cytokine IL-10 was not altered by exposition to both probiotics only. However, except for the H92/3 strain, EAEC strains' infection reduced IL-10 levels compared to baseline production, although with no statistical difference (FIGURE 4). The presence of both probiotics held IL-

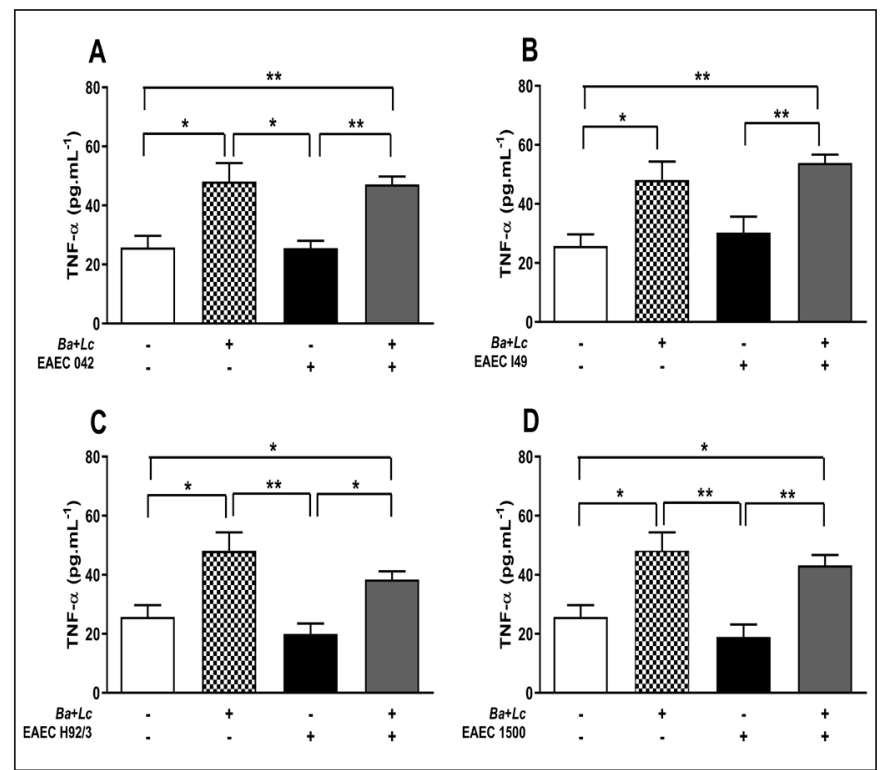

FIGURE 3. TNF- $\alpha$ production by uninfected Caco- 2 cells (basal production), exposed to both probiotic strains $(B a+L c)$ and to EAEC 042 (A), I49 (B) H92/3 (C) and 1500 (D) strains in the absence and in the presence of both probiotics. Co-cultivation lasted for three hours and cells were cultured for additional 21 hours. Results are expressed as mean and S.E.M from three experiments performed independently. EAEC: Enteroaggregative Escherichia coli; Ba: Bifidobacterium animalis; Lc: Lactobacillus casei. Differences between culture conditions were calculated using Mann-Whitney test. $* P<0.05$; $* * P<0.01$.

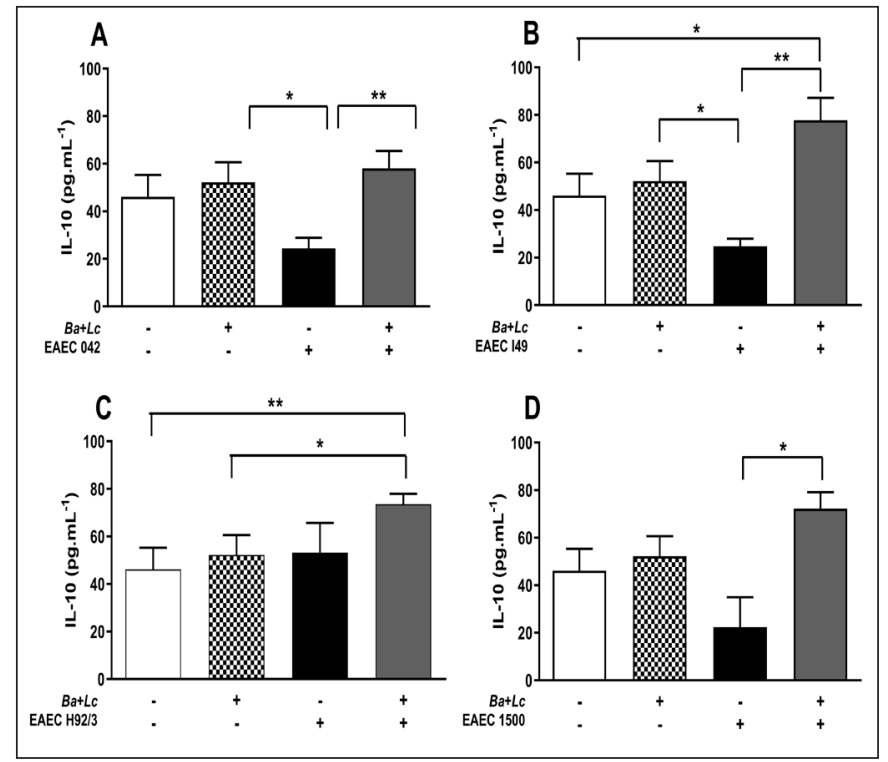

FIGURE 4. IL-10 production by uninfected Caco-2 cells (basal production), exposed to both probiotic strains $(B a+L c)$ and to EAEC $042(\mathrm{~A}), \mathrm{I} 49$ (B) $\mathrm{H} 92 / 3$ (C) and 1500 (D) strains in the absence and in the presence of both probiotics. Co-cultivation lasted for three hours and cells were cultured for additional 21 hours. Results are expressed as mean and S.E.M from three experiments performed independently. EAEC: Enteroaggregative Escherichia coli; Ba: Bifidobacterium animalis; Lc: Lactobacillus casei. Differences between culture conditions were calculated using Mann-Whitney test. $* P<0.05 ; * * P<0.01$. 
10 levels similar to basal levels but statistically higher than that induced by the infection with $042 \operatorname{strain}(P=0.0152$, FIGURE 4.A) and I49 strain $(P=0.0346$, FIGURE 4.B). Notably, co-cultivation of both probiotics in the presence of EAEC strains induced a significant increase in the amount of IL-10 compared to that produced only in the presence of $042(P=0.0065$, FIGURE 4.A), I49 $(P=0.0043$, FIGURE 4.B $)$ and $1500(P=0.0216$, FIGURE 4.D) EAEC strains. The association of both probiotics and EAEC H92/3 strain increased IL-10 levels compared to basal production and cells exposed to both probiotics only $(P=0.0065$ and $P=0.026$, respectively, FIGURE 4.C).

\section{DISCUSSION}

Diarrhoeagenic Escherichia coli (DEC) strains are highlighted as the most common intestinal infections cause among enteric pathogens. As a common characteristic, E. coli pathotypes included in DEC group colonize mucosa by adhering to IECs, often evading host defenses and causing tissue damage. These events are often associated with alteration in water absorption and electrolytes, causing diarrhea. EAEC is the most frequently detected pathotype in acute and persistent diarrhea in children cases worldwide ${ }^{(1,23,24)}$.

The mucosa is an essential component of natural immunity, acting as a barrier to microorganisms. When an enteric pathogen overcomes this host defense, IECs can induce an inflammatory response, resulting in intestinal damage and symptoms associated with the infection ${ }^{(9,12,13)}$. Studies have shown the association between virulence factors and stimulation of cytokine production in EAEC infection. Increased levels of the cytokines IL-1 $\beta$, IL- 8 , IFN- $\gamma$ and other inflammatory markers in stool samples, such as lactoferrin, gross mucus, leukocytes and occult blood, are related to some virulence factors, including AggR, AAFs, dispersin and flagellin ${ }^{(2,11,25-28)}$.

Several studies have adopted in vitro cell infection model to investigate cytokine production induced by EAEC infection. Braga et al. ${ }^{(11)}$ studied three of the four strains used in this work (042, I49 and H92/3). The authors observed that all EAEC strains induced IL-8 production by differentiated T84 cells. Other studies also show that Caco- 2 cells produce IL-8 in vitro after EAEC infection ${ }^{(2,26)}$. IL-8 is associated with the inflammatory response of EAEC infection and is a central interleukin involved in polymorphonuclear (PMN) leukocyte chemotaxis ${ }^{(2)}$. In our study, EAEC strains were evaluated for inducing cytokine production in polarized and differentiated Caco-2 cells. Our results corroborate previous studies, once all EAEC strains induced IL-8 production and EAEC 042, I49 and H92/3 strains present AAFs and aggR transcriptional activator. These virulence factors are related to inflammatory response, which could explain the high IL-8 production by infected Caco- 2 cells ${ }^{(11,25,26)}$. We will further perform the genotypic characterization of EAEC 1500 strain.

The production of other pro-inflammatory cytokines besides IL-8 has been reported. Using the cell line HCT- 8 derived from colonic adenocarcinoma, Cennimo et al. ${ }^{(27)}$ detected increased IL-8, IL- 6 and TNF- $\alpha$ production induced by EAECs expressing AggR. Using the same cell line and measuring mRNA expression, Medeiros et al. ${ }^{(29)}$ observed that the strain EAEC 042 induced the expression of IL-8 and TNF- $\alpha$, which did not occur with IL-6. Also, this strain reduced the expression of TGF- $\beta$. Braga et al. ${ }^{(11)}$ also observed the stimulation of IL- 6 and TNF- $\alpha$ production by T84 cells infected with EAEC 042 and I49 strains. Although we observed an increase in IL-8 levels, we did not detect an increase in the production of IL- $1 \beta$ and TNF- $\alpha$ by Caco- 2 cells infected with
EAEC strains, which may be associated with low TLR expression at IECs apical membrane under homeostatic conditions ${ }^{(30)}$ or due to the different IEC used in our system.

Probiotics are microorganisms that colonize surfaces such as mucosa and confer benefits to the host and their prophylactic or therapeutic use is related to action against intestinal dysbiosis, especially antibiotic-associated diarrhea and infectious diarrhea ${ }^{(31,32)}$. Probiotic bacteria, especially Bifidobacterium and Lactobacillus species, may inhibit growth, toxin production and other virulence factors expression of pathogenic microorganisms ${ }^{(33)}$.

Probiotics also play an important role in the development of mucosal immunity. Ogawa et al. ${ }^{(34)}$ identified high levels of antiStx 1 and $2 \operatorname{IgA}$ in Shiga toxin-producing E. coli-infected rabbits after $L$. casei treatment, decreasing intestine toxin concentration of the animals. Ashraf and Shah ${ }^{(35)}$ also associated immunological mechanisms, including higher numbers of IgA+ cells in animals' intestines, to the administration of probiotic bacteria B. animalis, L. johnsonii, B. lactis and the yeast Saccharomyces boulardii. The immunomodulatory properties of probiotics have been linked to TLR and NF- $x$ B activation pathways. Karlsson et al. ${ }^{(36)}$ found that a L. rhamnosus strain increases $\mathrm{NF}-x \mathrm{~B}$ expression of uropathogenic E. coli-infected bladder cells by TLR-4 activation, with increased TNF- $\alpha$ production. Jung et al. ${ }^{(37)}$ observed that a $L$. sakei strain increased phagocytic activity and induced nitric oxide (NO) production, IL- 6 and TNF- $\alpha$ by probiotic-exposed macrophages through activation of NF- $x \mathrm{~B}$. This inflammatory response was related to TLR-2 activation since the authors observed that the blockage of TLR-2 inhibited NO production. Rocha-Ramírez et al. ${ }^{(38)}$ also obtained similar results in which lactobacilli strains led to NF- $x \mathrm{~B}$ activation and the production of activated macrophage-related cytokines as a TLR-2-dependent inflammatory response.

Multispecies synergism is an essential factor in the action of probiotics against pathogens ${ }^{(39)}$. Lee et al. ${ }^{(16)}$ demonstrated that yogurt consumption containing $B$. animalis, $L$. paracasei and $L$. plantarum together is related to increased NK cell action, suggesting that multiple probiotic sources may have a positive effect on host immune response. In this study, B. animalis and $L$. casei separately were unable to modulate cytokine production by Caco-2 cells exposed to different EAECs strains, suggesting that these probiotics strains better act synergistically.

In our study, EAEC strains induced IL-8 production, and probiotics could not reduce its production. Probiotics induced a reduction in IL-1 $\beta$ production when compared to non-infected Caco- 2 cells. Additionally, probiotics were able to reduce IL-1 $\beta$ levels induced by EAEC I49 strain. Interestingly, EAEC infected and non-infected Caco-2 cells exposed to probiotics produced higher amounts of TNF- $\alpha$.

The absence of the modulation in IL-8 production and the induction of increased TNF- $\alpha$ levels by probiotic-exposed Caco-2 cells conflict with some results of previous studies using co-cultivation in vitro models ${ }^{(40,41)}$. Jiang et al. ${ }^{(40)}$ demonstrated that L. plantarum decreased the expression of pro-inflammatory cytokines induced by Salmonella typhimurium in Caco-2 cells but had no effect on IL-10 expression. Recently, Kim et al. ${ }^{(41)}$ have shown that $L$. acidophilus reduced the expression of TNF- $\alpha$ while increasing IL-10 expression in RAW-macrophages stimulated with LPS. On the other hand, different studies have shown that TNF- $\alpha$ production is at least in part dependent on NF- $x \mathrm{~B}$ activation and that TLR expression is induced in IECs exposed to probiotics. In this way, the increase in TNF- $\alpha$ production by probiotic-exposed 
and infected Caco-2 cells observed in our system may be related to the signaling pathway of TLR responsive to probiotics and surface molecules present in enterobacteria, such as $\operatorname{LPS}^{(30,36-38,42)}$.

IL-10 has a regulatory function of the immune response by inhibiting the inflammatory response. We found that Caco-2 cells infected with three of the four EAEC strains and treated with probiotics produced higher levels of IL-10 than untreated cells, highlighting the immunomodulatory properties of probiotics as previously described ${ }^{(40,41)}$.

This study demonstrates the synergistic activity of probiotics $B$. animalis and $L$. casei in modulating inflammation induced by EAEC in Caco- 2 cells.

\section{Authors' contribution}

Ferreira AF: survey execution, data analysis, writing of text. Braga RLL: survey execution. Andrade MF: survey execution. Rosa ACP: designed the research, data analysis, writing of text. PereiraManfro WF: designed the research, data analysis, writing of text.

\section{Orcid}

Andréa Fonseca Ferreira: 0000-0001-7490-8546.

Ricardo Luís Lopes Braga: 0000-0002-1896-0144.

Maysa Ferreira Andrade: 0000-0002-6613-5800.

Ana Claudia de Paula Rosa: 0000-0002-3308-1922.

Wânia Ferraz Pereira Manfro: 0000-0003-0166-8144.

Ferreira AF, Braga RLL, Andrade MF, Rosa ACP, Pereira-Manfro WF. Atividade imunomoduladora sinérgica de probióticos Bifidobacterium animalis e Lactobacillus casei em células Caco-2 infectadas com Escherichia coli enteroagregativa (EAEC). Arq Gastroenterol. 2021;58(4):433-8.

RESUMO - Contexto - Escherichia coli enteroagregativa (EAEC) é um patotipo de E. coli que apresenta o padrão de aderência agregativa em células cultivadas in vitro, sendo comumente relacionada a casos de diarreia persistente em crianças. Fatores de virulência presentes em EAEC são importantes para a colonização do hospedeiro e patogenicidade. As células epiteliais intestinais (IECs) reconhecem padrões moleculares associados a patógenos (PAMPs) e iniciam uma resposta imune. Vários estudos usando modelos in vivo e in vitro enfatizam a atividade probiótica e a capacidade imunomoduladora de espécies de Lactobacillus e Bifidobacterium. Objetivo - Este estudo avaliou a modulação da produção de citocinas pelos probióticos Bifidobacterium animalis and Lactobacillus casei em células intestinais humanas Caco-2 expostas a diferentes cepas de EAEC. Métodos - As células Caco-2 foram incubadas com as cepas de EAEC na presença ou ausência dos probióticos. A produção das citocinas IL- 8 , TNF- $\alpha$, IL-1 $\beta$ e IL-10 foi avaliada nos sobrenadantes por ELISA sanduíche. Resultados - Não houve alteração na produção de citocinas quando as células não infectadas e as células infectadas com EAEC foram expostas aos probióticos separadamente. Todas as cepas de EAEC induziram aumento significativo na produção de IL-8 pelas células Caco-2, mas os probióticos, ainda que em conjunto, não foram capazes de reduzir a produção desta citocina. Por outro lado, as cepas de probióticos aumentaram significativamente a produção de TNF- $\alpha$ mas diminuíram a produção basal de IL-1B. Além disso, os probióticos induziram um aumento significativo na produção da citocina anti-inflamatória IL-10 durante a infecção por EAEC. Conclusão - Nossos resultados reforçam a atividade imunomodulatória sinérgica dos probióticos durante a infecção de EAEC.

Palavras-chave - Escherichia coli; probióticos; Bifidobacterium animalis; Lactobacillus casei; citocinas; células epiteliais; imunidade.

\section{REFERENCES}

1. Nataro JP, Kaper JB. Diarrheagenic Escherichia coli. Clin Microbiol Rev. 1998;11:142-201.

2. Estrada-Garcia T, Perez-Martinez I, Bernal-Reynaga R, Zaidi MB. Enteroaggregative Escherichia coli: A Pathogen Bridging the North and South. Curr Trop Med Reports. 2014;1:88-96

3. Lima AAM, Medeiros PHQS, Havt A. Enteroaggregative Escherichia coli subclinical and clinical infections. Curr Opin Infect Dis. 2018;31:433-9.

4. Clements A, Young JC, Constantinou N, Frankel G. Infection strategies of enteric pathogenic Escherichia coli. Gut Microbes. 2012;3:71-87.

5. Chattaway MA, Harris R, Jenkins C, Tam C, Coia JE, Gray J, et al. Investigating the link between the presence of enteroaggregative Escherichia coli and infectious intestinal disease in the United kingdom, 1993 to 1996 and 2008 to 2009. Euro Surveill. 2013;18:20582.

6. Gupta D, Sharma M, Sarkar S, Thapa BR, Chakraborti A. Virulence determinants in enteroaggregative Escherichia coli from North India and their interaction in in vitro organ culture system. FEMS Microbiol Lett. 2016;363:fnw189.

7. Havt A, Lima IF, Medeiros PH, Clementino MA, Santos AK, Amaral MS, et al. Prevalence and virulence gene profiling of enteroaggregative Escherichia coli in malnourished and nourished Brazilian children. Diagn Microbiol Infect Dis. 2017;89:98-105.

8. Abe CM, Knutton S, Pedroso MZ, Freymüller E, Gomes TAT. An enteroaggregative Escherichia coli strain of serotype O111:H12 damages and invades cultured T84 cells and human colonic mucosa. FEMS Microbiol Lett. 2001;203:199-205.

9. Hebbelstrup Jensen B, Olsen KEP, Struve C, Krogfelt KA, Petersen AM. Epidemiology and clinical manifestations of enteroaggregative Escherichia coli. Clin Microbiol Rev. 2014;27:614-30.

10. Khan K, Konar M, Goyal A, Ghosh S. Enteroaggregative Escherichia coli infection induces IL-8 production via activation of mitogen-activated protein kinases and the transcription factors NF- $x$ B and AP-1 in INT-407 cells. Mol Cell Biochem. 2010;337:17-24.
11. Braga RLL, Pereira ACM, Ferreira AF, Rosa AC de P, Pereira-Manfro WF. Intracellular persistence of enteroaggregative Escherichia coli induces a proinflammatory cytokines secretion in intestinal epithelial T84 cells. Arq Gastroenterol. 2018;55:133-7.

12. Kawai T, Akira S. Toll-like receptors and their crosstalk with other innate receptors in infection and immunity. Immunity. 2011;34:637-50.

13. Kinnebrew MA, Pamer EG. Innate immune signaling in defense against intestinal microbes. Immunol Rev. 2012;245:113-31.

14. Reid G, Jass J, Sebulsky MT, McCormick JK. Potential uses of probiotics in clinical practice. Clin Microbiol Rev. 2003;16:658-72.

15. Liévin-Le Moal V, Servin AL. Anti-infective activities of Lactobacillus strains in the human intestinal microbiota: from probiotics to gastrointestinal anti- infectious biotherapeutic agents. Clin Microbiol Rev. 2014;27:167-99.

16. Lee A, Lee YJ, Yoo HJ, Kim M, Chang Y, Lee DS, et al. Consumption of dairy yogurt containing Lactobacillus paracasei ssp. paracasei, Bifidobacterium animalis ssp. lactis and Heat-Treated Lactobacillus plantarum improves immune function including natural killer cell activity. Nutrients. 2017;9:558-66.

17. Makarova K, Slesarev A, Wolf Y, Sorokin A, Mirkin B, Koonin E, et al. Comparative genomics of the lactic acid bacteria. Proc Natl Acad Sci U S A. 2006;103:15611-6.

18. Ferreira AF, Pereira-Manfro WF, Rosa AC de P. Diarrheagenic Escherichia coli and Probiotic Activity against Foodborne Pathogens: A Brief Review. Gastroenterol Hepatol Open Access. 2017;7:00248. DOI: 10.15406/ghoa.2017.07.00248.

19. Nataro JP, Scalestsky ICA, Kaper JB, Levine MM, Trabulsi LR. Plasmid-mediated factors conferring diffuse and localized adherence of enteropathogenic Escherichia coli. Infect Immun. 1985;48:378-83.

20. Rosa ACP, Mariano AT, Pereira AMS, Tibana A, Gomes TAT, Andrade JRC. Enteropathogenicity markers in Escherichia coli isolated from infants with acute diarrhoea and healthy controls in Rio de Janeiro, Brazil. J Med Microbiol. 1998;47:781-90 
21. França FLS, Wells TJ, Browning DF, Nogueira RT, Sarges FS, Pereira AC, et al Genotypic and Phenotypic Characterisation of Enteroaggregative Escherichia coli from Children in Rio de Janeiro, Brazil. PLoS One. 2013;8:1-9.

22. Rosa ACP, Vieira MAM, Tibana A, Gomes TAT, Andrade JRC. Interactions of Escherichia coli strains of non-EPEC serogroups that carry eae and lack the EAF and stx gene sequences with undifferentiated and differentiated intestinal human Caco-2 cells. FEMS Microbiol Lett. 2001;200:117-22.

23. Edwards LA, Bajaj-Elliott M, Klein NJ, Murch SH, Phillips AD. Bacterial-epithelial contact is a key determinant of host innate immune responses to enteropathogenic and enteroaggregative Escherichia coli. PLoS One. 2011;6: e27030.

24. Boisen N, Krogfelt KA, Nataro JP. Enteroaggregative Escherichia coli. In: Escherichia coli: Pathotypes and Principles of Pathogenesis: Second Edition. 2013. p. 247-73.

25. Steiner TS, Lima AAM, Nataro JP, Guerrant RL. Enteroaggregative Escherichia coli produce intestinal inflammation and growth impairment and cause interleukin-8 release from intestinal epithelial cells. J Infect Dis. 1998;177:88-96.

26. Steiner TS, Nataro JP, Poteet-Smith CE, Smith JA, Guerrant RL. Enteroaggregative Escherichia coli expresses a novel flagellin that causes IL-8 release from intestinal epithelial cells. J Clin Invest. 2000;105:1769-77.

27. Cennimo D, Abbas A, Huang DB, Chiang T. The prevalence and virulence characteristics of enteroaggregative Escherichia coli at an urgentcare clinic in the USA: A case-control study. J Med Microbiol. 2009;58:403-7.

28. Mercado EH, Ochoa TJ, Ecker L, Cabello M, Durand D, Barletta F, et al. Fecal leukocytes in children infected with diarrheagenic Escherichia coli. J Clin Microbiol. 2011;49:1376-81.

29. Medeiros P, Bolick DT, Roche JK, Noronha F, Pinheiro C, Kolling GL, et al. The micronutrient zinc inhibits EAEC strain 042 adherence, biofilm formation, virulence gene expression, and epithelial cytokine responses benefiting the infected host. Virulence. 2013;4:624-33.

30. de Kivit S, Tobin MC, Forsyth CB, Keshavarzian A, Landay AL. Regulation of intestinal immune responses through TLR activation: Implications for pro- and prebiotics. Front Immunol. 2014;5:60.

31. Goldin BR. Health benefits of probiotics. Br J Nutr. 1998;80:203-7.
32. Ritchie ML, Romanuk TN. A meta-analysis of probiotic efficacy for gastrointestinal diseases. PLoS One. 2012;7:e34938.

33. Abd El-Moez SI, Ahmed FY, Samy AA, Ali AR. Probiotic activity of L. acidophilus against major food-borne pathogens isolated from broiler carcasses. Nat Sci. 2010;8:69-78

34. Ogawa M, Shimizu K, Nomoto K, Takahashi M, Watanuki M, Tanaka R, et al. Protective effect of Lactobacillus casei strain Shirota on Shiga toxin-producing Escherichia coli O157:H7 infection in infant rabbits. Infect Immun. 2001;69:1101-8.

35. Ashraf R, Shah NP. Immune System Stimulation by Probiotic Microorganisms. Crit Rev Food Sci Nutr. 2014;54:938-56.

36. Karlsson M, Scherbak N, Reid G, Jass J. Lactobacillus rhamnosus GR-1 enhances NF-kappaB activation in Escherichia coli-stimulated urinary bladder cells through TLR4. BMC Microbiol. 2012;12:15.

37. Jung JY, Shin JS, Lee SG, Rhee YK, Cho CW, Hong H Do, et al. Lactobacillus sakei K040706 evokes immunostimulatory effects on macrophages through TLR 2-mediated activation. Int Immunopharmacol. 2015;28:88-96.

38. Rocha-Ramírez LM, Pérez-Solano RA, Castañón-Alonso SL, Moreno Guerrero SS, Ramírez Pacheco A, García Garibay M, et al. Probiotic Lactobacillus Strains Stimulate the Inflammatory Response and Activate Human Macrophages. J Immunol Res. 2017;2017:4607491.

39. Kumar M, Dhaka P, Vijay D, Vergis J, Mohan V, Kumar A, et al. Antimicrobia effects of Lactobacillus plantarum and Lactobacillus acidophilus against multidrug-resistant enteroaggregative Escherichia coli. Int J Antimicrob Agents. 2016;48:265-70

40. Jiang M, Zhang F, Wan C, Xiong Y, Shah NP, Wei H, et al. Evaluation of probiotic properties of Lactobacillus plantarum WLPL04 isolated from human breast milk. J Dairy Sci. 2016;99:1736-46.

41. Kim DH, Kim S, Lee JH, Kim JH, Che X, Ma HW, et al. Lactobacillus acidophilus suppresses intestinal inflammation by inhibiting endoplasmic reticulum stress. J Gastroenterol Hepatol. 2019;34:178-85.

42. Vizoso Pinto MG, Rodriguez Gómez M, Seifert S, Watzl B, Holzapfel WH, Franz CMAP. Lactobacilli stimulate the innate immune response and modulate the TLR expression of HT29 intestinal epithelial cells in vitro. Int J Food Microbiol. 2009;133:86-93 